\title{
The Effect of Regional Financial Supervision, Accountability and Transparency of Regional Financial Management on Local Government Performance
}

\author{
Vincentia Wahju Widajatun ${ }^{1}$, Francisca Kristiastuti ${ }^{2}$ \\ ${ }^{1}$ Universitas Widyatama, Indonesia \\ ${ }^{2}$ Universitas Nurtanio Bandung, Indonesia \\ vincentia.wahju@widyatama.ac.id,francisca.lulu75@gmail.com
}

\begin{abstract}
This study aims to determine the effect of regional financial supervision on local government performance, the effect of regional financial management accountability on regional government performance, to determine the effect of transparency in regional financial management on regional government performance, and the effect of regional financial supervision, accountability and transparency of regional financial management on performance. Regional government. This research was conducted in West Bandung Regency. The sampling technique used non-probability sampling techniques so that the samples in this study were 34 people. The type of data used in this research is quantitative and qualitative data, while the data source is the primary data source. The method of data collection is done by using a questionnaire. The data analysis technique used multiple linear regression analysis with the help of the SPSS 24.0 program. The results of this study indicate that simultaneously regional financial supervision, accountability and financial management transparency have a significant effect on the performance of local governments. Regional Financial Supervision has no significant effect on Local Government performance, financial management accountability has a significant effect on Local Government performance, financial management transparency has a significant effect on Local Government performance.
\end{abstract}

Keywords

supervision; accountability, transparency, local government performance

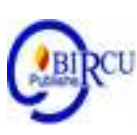

\section{Introduction}

The issue of local government performance is currently in the public spotlight because it has not shown good results felt by the people. The people demand that the government has a good performance in carrying out its duties and responsibilities as the embodiment of the concept of regional autonomy. Mahsun (2006) in Wiguna (2015) says that performance itself is work ability shown by work results. The government is said to have a good performance if the government is able to manage the government so that it can provide welfare to its people as a whole.

The high number of public assumptions regarding the implementation of regional autonomy has caused government performance to become one of the issues in the public spotlight. This is because the community has not felt the maximum results of government performance (Auditya et al., 2013). As a public sector organization, the government is required to perform well in carrying out its duties and responsibilities. The demand for good government performance has occurred in almost all governments with the application of the concept of regional autonomy and the enactment of laws related to government management, including the government in West Bandung Regency. 
According to Nuraflah (2020) One of the important points related to village authority in carrying out its own government is to carry out village development. The performance of government agencies is closely related to supervision, transparency accountability. Strengthening accountability mechanisms requires good performance management. The application of various existing laws and regulations related to the application of the concept of accountability and transparency in financial management is expected to realize good and pro-people management of local governments. The implementation of accountability and transparency in regional financial management is expected to be able to improve the performance of local governments. Angelia et al., (2020) stated that important to know empowerment to the involvement of village community organizations as village government partners in assisting the performance of the Village Government to achieve development goals in the village.

The public demand for the government is to produce financial reports that fulfill the four qualitative characteristics of these financial statements. The financial report is an accountability tool for the financial performance of the management of a government to the public entrusted to it (Prasetyo, 2015). Financial reports aim to reflect whether a government has been running well, so that the government is required to be able to produce quality financial reports. Where the resulting reports have met the qualitative characteristics of financial reports which consist of relevant, reliable, comparable and understandable (Herawati and Darmawan, 2014).

In financial management, it must refer to the Regulation of the Minister of Finance of the Republic of Indonesia Number 177/PMK.05/2015 concerning Guidelines for the Preparation and Submission of Financial Statements of State Ministries/Institutions starting from budget preparation, budget implementation to the accountability of regional budget users. The following is the assessment data received by West Bandung Regency in 20152019:

Table 1. List of Financial Examination Agency Audit Opinions on the Financial Statements of the Regional Government of West Bandung Regency 2012-2019

\begin{tabular}{|c|c|c|}
\hline No & Year & Opinion of Financial Examination Agency \\
\hline 1 & 2015 & Reasonable With Exceptions (Qualified Opinion) \\
\hline 2 & 2016 & Reasonable With Exceptions (Qualified Opinion) \\
\hline 3 & 2017 & Reasonable With Exceptions (Qualified Opinion) \\
\hline 4 & 2018 & Reasonable With Exceptions (Qualified Opinion) \\
\hline 5 & 2019 & Reasonable With Exceptions (Qualified Opinion) \\
\hline
\end{tabular}

Source: www.bpk.go.id

In Table 1, it is proven by the submission of the Regional Government Financial Reports Audit Opinion Development Report for Fiscal Year 2015-2019 by the Financial Examination Agency which provides a Fair opinion with the exception of West Bandung Regency. This assessment means that there has been no significant development in the financial management of the West Bandung Regency Government, so that currently the West Bandung Regency Government continues to fail to achieve the achievement to get an Unqualified opinion. When the Financial Examination Agency provides an opinion on the financial statements of a regional government, it means that it can be said that the financial statements of a regional government entity are presented and disclosed in a fair and high quality manner. Even though the West Bandung Regency Government does not indicate financial abuse, the West Bandung Regency Government is unable to obtain fair without 
exception, which means that it has not been said that the financial statements are honest, accurate, transparent, and obeying laws and regulations.

The rapid development of public sector organizations requires the government to perform well in carrying out its duties and responsibilities. The government's performance is said to be good, it can be seen from the level of achievement of results which is implemented real and maximally. The performance of an organization that has been implemented with a certain level of achievement must be in accordance with the vision and mission of the organization which has been established as a basis for carrying out tasks that must be accounted for (Mahsun, 2006: 4) in (Wiguna 2015).

To determine the level of achievement of the implementation of an activity / program whether it is successful or not, performance measurement is required as a measurement tool. Performance measurement helps local government officials determine the level of achievement of goals and helps citizens to evaluate whether the level of services provided by the government is equivalent to the money they spend on these services (Ulum,2012: 20).

Supervision of regional financial management is very important, because supervision is an effort to ensure harmony between the implementation of government tasks in the regions (central) and ensuring the smooth running of the government in an efficient manner (Halim, 2002) in (Purnama, 2016). Supervision is a real and most effective action in realizing discipline of organizational employees (Hasibuan, 2009) in (Wiguna, 2015). Furthermore, Hasibuan (2009) in (Wiguna, 2015) states that the factors that influence an employee's work discipline are goals and abilities, leadership role models, remuneration, justice, inherent supervision, legal sanctions and firmness. Supervision is very important in every job. Because with good supervision, a job will run smoothly and can produce optimal work results. The smoother the work and accompanied by good supervision, the work will be successful. With good supervision, it will encourage employees to be more active in working and produce good work, especially when completing their work in good spirits.

On the one hand, accountability is needed as a form of government accountability to society. Public accountability is a principle of public accountability which means that the budgeting process starting from planning, preparation and implementation must be properly reported and accountable to the Regional House of Representatives and the public. One of the principles of regional financial management is accountability. Accountability requires that decision-making behaves in accordance with the mandate it receives. Important aspects that must be considered are: 1) the legality aspect of regional revenues and expenditures, that every transaction carried out must be tracked by its legal authority, 2) aspects of good regional financial management (sterwarship), protection of physical and financial assets preventing waste and mismanagement. For this, the formulation of policies, together with the means and results of these policies must be accessible and well communicated vertically and horizontally (Mardiasmo, 2006).

Increasing human resources has implications for improving organizational performance and is a management tool for realizing one's professionalism in structural and functional positions (Irfansyah, 2020). Transparency in the management of regional finances is an important factor in improving the performance of local governments, because it is one of the principles of good governance. Transparency is the openness of the government in providing information related to public resource management activities to parties who need information (Adisasmita, 2011: 39). Furthermore, Mardiasmo (2004: 30) states that the government is obliged to provide financial and other information which is used in making economic, social and political decisions by stakeholders.

In making this decision, accounting information is needed, one of which is in the form of financial reports. The results of research by Adiwirya and Sudana (2015) also state that 
transparency has an effect on the performance-based budget of Regional Work Units. This result is in line with previous research conducted by Auditya et al., (2013). Research results from Auditya et al., (2013) state that financial management transparency has a positive and significant effect on the performance of Regional Work Units.

The benefit of this research is that theoretically the results of this study are expected to contribute to the knowledge of accounting science, especially with regard to supervision, accountability and transparency of regional finances in order to improve performance, then the practical benefits of this research are expected to provide experience and insight that have been gained through theory -the theory that has been obtained in college with the reality in the field and this research is expected to be used as material for consideration for local governments in the field of public sector accounting related to financial management supervision and accountability in order to improve local government performance.

The link between supervision and performance can also be seen from the opinion of Menzeis (quoted by Rahayu, 2008), which states that performance can be improved with good supervision, the leader must have the supervisory system he needs to direct his subordinates appropriately. Based on the description, the first hypothesis can be formulated, namely:

\section{H1: Supervision of regional financial management has a significant effect on the performance of local governments}

Accountability includes providing financial information to the public and other users so that it is possible for them to assess the government's accountability for all activities undertaken, not just financial activities. This concept emphasizes that government financial reports as government management (performance) must be able to provide the information needed by users in making economic, social and political decisions (Halim, 2002). Based on the description, the second hypothesis can be formulated, namely:

\section{H2: Regional financial management accountability has a significant effect on local government performance}

According to Garini (2011), transparency has a significant effect on the performance of government agencies. The manifestation of transparency as a mandate of laws and regulations in government management has put pressure on government management officials to open themselves up to the rights of the public to obtain the widest possible information correctly, honestly and non-discriminatively about the implementation of regional government. This reasoning will make the government apparatus show their best performance in carrying out their duties and responsibilities so that they will work in accordance with applicable regulations, so the local government will automatically perform well. Based on the description, the third hypothesis can be formulated, namely:

\section{H3: Transparency of regional financial management has a significant effect on the performance of local governments.}

Menzeis (quoted by Rahayu, 2008), which states that performance can be improved with good supervision, a leader must have a supervisory system that he needs to direct his subordinates appropriately. Garnita (2008) conducted a study on the Effect of Accountability on the Performance of Government Agencies, the results show that accountability has a positive and significant effect on the performance measurement of government agencies.

The application of the principle of transparency in the administration of regional government provides an opportunity for the public to find out various information about the implementation of regional government in a correct, honest and non-discriminatory manner. 
(best performance) to the community by increasing the achievement of government goals in accordance with the vision and mission (Rahmanurrasjid, 2008). Based on this, the following hypothesis can be formulated:

\section{H4: Supervision, accountability and transparency of regional financial management have a significant effect on the performance of local governments}

\section{Research Methods}

This research design uses a qualitative descriptive design which is included in the type of experimental research, namely a study that seeks to find the effect of certain variables on other variables in tightly controlled conditions which is a causal or causal research. Sugiyono (2012: 7). This study looks for the influence of regional financial supervision, accountability and transparency of regional financial management both simultaneously and partially on the performance of local governments.

The location of this research is in West Bandung Regency. The subjects of this research are all employees of the Inspectorate of West Bandung Regency as a supervisory body that is directly responsible to the Regent while the object of this research is the supervision of regional finances, accountability and transparency of Regional Financial management and the performance of Local Government.

The population in this study were all employees of the BandungBarat Regency Inspectorate, totaling 52 people (source, Section of Employee Administration, 2020). The sampling technique for Nonprobability Sampling is purposive sampling, which is a sampling technique with certain considerations involving only certain areas such as supervision and auditing. This is in accordance with the issues raised, namely related to the supervision of financial management, accountability and transparency of financial management on the performance of local governments so that 34 people were sampled in this study.

The types of data used in this research are quantitative data types and qualitative data types. Based on the source, the data used are primary data, while the data collection methods used are documentation and questionnaires. Furthermore, the research instrument used will be tested using the validity test and reliability test. The data analysis method used is the first, Classical Assumption Test, then analyzed using Multiple Linear Regression Analysis, TTest Analysis and, F-Test Analysis.

\section{Discussion and Results}

Based on data collection in the field using a questionnaire method related to regional financial supervision, accountability and transparency of regional financial management on the performance of the West Bandung Regency local government, descriptive statistical analysis was carried out using the assistance of SPSS 24.0.

\subsection{Validity and Reliability Testing}

Table 2. Regional Financial Supervision

\begin{tabular}{|r|r|}
\hline \multicolumn{2}{|c|}{ Reliability Statistics } \\
\hline Cronbach's Alpha & N of Items \\
\hline .938 & 10 \\
\hline
\end{tabular}


Table 3. Accountability

Reliability Statistics

\begin{tabular}{|r|r|}
\hline Cronbach's Alpha & N of Items \\
\hline .907 & 9 \\
\hline
\end{tabular}

Table 4. Transparency of Regional Financial Management

\begin{tabular}{|r|c|}
\hline \multicolumn{2}{|c|}{ Reliability Statistics } \\
\hline Cronbach's Alpha & N of Items \\
\hline .925 & 10 \\
\hline
\end{tabular}

Table 5. Local Government Performance

\begin{tabular}{|r|r|}
\hline \multicolumn{2}{|c|}{ Reliability Statistics } \\
\hline Cronbach's Alpha & N of Items \\
\hline .904 & 7 \\
\hline
\end{tabular}

Source: Primary Data processed using SPSS 24

Based on the tables above, it can be concluded that all statement items in the research questionnaire are declared valid and reliable. This can be seen from the value of the cronbach alpha value greater than 0.60 .

\subsection{Partial Hypothesis Test (t test)}

Table 6. Multiple Linear Regression

\begin{tabular}{|c|c|c|c|c|c|c|}
\hline \multicolumn{7}{|c|}{ Coefficients $^{\mathbf{a}}$} \\
\hline & \multirow[b]{2}{*}{ Model } & \multicolumn{2}{|c|}{$\begin{array}{l}\text { Unstandardized } \\
\text { Coefficients }\end{array}$} & \multirow[b]{2}{*}{$\mathrm{t}$} & \multirow[b]{2}{*}{ Sig. } & \multirow[b]{2}{*}{ Information } \\
\hline & & $\mathrm{B}$ & Std. Error & & & \\
\hline \multirow[t]{4}{*}{1} & (Constant) & 2.728 & 2.762 & .988 & .331 & \\
\hline & $\begin{array}{l}\text { Regional Financial } \\
\text { Supervision }\end{array}$ & .146 & .111 & 1.321 & .196 & $\begin{array}{r}\text { Not } \\
\text { Affected }\end{array}$ \\
\hline & Accountability & .206 & .077 & 2.691 & .012 & Affected \\
\hline & $\begin{array}{l}\text { Regional Financial } \\
\text { Management Transparency }\end{array}$ & .315 & .095 & 3.320 & .002 & Affected \\
\hline
\end{tabular}

Based on table 6 , it can be seen at the $5 \%$ significance level, if $t_{\text {count }} \geq t_{\text {table }}$ then $H_{a}$ is accepted and $H_{o}$ is rejected. Likewise, if $t_{\text {count }} \leq t_{\text {table }}$, then it accepts $H_{o}$ and rejects $H_{a}$. So it can be concluded that the Regional Financial Supervision has no effect on the Performance of Local Government, then for the variable Accountability and transparency variable Regional Financial Management affects the Performance of Local Government.

\subsection{Simultaneous Hypothesis Test (Test F)}

Table 7. Results of testing the hypothesis

\begin{tabular}{|l|l|r|r|r|c|c|}
\hline \multicolumn{7}{|c|}{ ANOVA $^{\mathrm{a}}$} \\
\hline \multicolumn{1}{|l|}{ Model } & Sum of Squares & \multicolumn{1}{c|}{ df } & Mean Square & F & Sig. \\
\hline \multirow{3}{*}{1} & Regression & 172.951 & 3 & 57.650 & 32.458 & $.000^{\mathrm{b}}$ \\
\cline { 2 - 7 } & Residual & 53.284 & 30 & 1.776 & & \\
\cline { 2 - 7 } & Total & 226.235 & 33 & & & \\
\hline
\end{tabular}


b. Predictors: (Constant), Regional Financial Management Transparency,

Accountability, Regional Financial Supervision

Based on table 7, the results of testing the hypothesis simultaneously, the value of Fcount is 32,458 while Ftable is 2.71 . So in accordance with the hypothesis proposed if Fcount> Ftable with a significance level of 5\%. It can be concluded that regional financial supervision, accountability, and transparency of regional financial management jointly affect the performance of local governments.

\section{Conclusion}

\subsection{Regional Financial Supervision, Accountability, and Transparency of Regional} Financial Management together have an effect on Local Government Performance

Based on the research results, Regional Financial Supervision, Accountability, and Transparency of Regional Financial Management jointly affect the Performance of Local Government. This shows that these variables are very important for the sustainability of local government performance.

\subsection{Regional Financial Supervision has no effect on Local Government Performance}

Based on the research results, Regional Financial Supervision has no effect on Local Government Performance. Regional financial supervision is one of the management functions that must be implemented properly in the implementation of government activities. The implementation of regional financial supervision can be a means to determine whether a government agency has carried out good and correct financial management. The results showed that the West Bandung Regency government did not yet have a good regional financial supervision system.

In contrast to research conducted by Wiguna et al., (2015) which shows that supervision of regional financial management has a significant effect on local government performance. This means that the better the level of regional financial supervision, the better the performance of local governments.

\subsection{Accountability Affects Local Government Performance}

Based on the research results, accountability has an effect on local government performance. Accountability is a form of local government accountability to the public regarding the implementation of government management that has been carried out. The research results prove that the accountability in the West Bandung Regency area can be said to be good. Thus, the higher and more accountable regional financial management, the more local government performance will increase.

\subsection{Transparency in Regional Financial Management affects the Performance of Local Governments}

Based on the research results, the transparency of regional financial management affects the performance of local governments. Transparency is important to apply. This is because the implementation of transparency in regional financial management is evidence of the government's seriousness in running a government that is clean, honest and free from all forms of irregularities. Thus, this can also prove the level of success of the government in managing finances and can improve government performance for the better (Wiguna et al., 215). This shows that the more transparent financial management and financial reporting, the more local government performance will increase. 


\section{References}

Adisasmita, Rahardjo. (2011). Manajemen Pemerintah Daerah. Graha Ilmu: Yogyakarta.

Adiwirya, M Firdiansyah., and Sudana Putu. (2015). Akuntabilitas, Transparansi Dan Anggaran Berbasis Kinerja Pada Satuan Kerja Perangkat Daerah Kota Denpasar. EJurnal Akuntansi.

Agus Nurrahmanto, Prasetyo. (2015). Pengaruh Kemudahan Penggunaan Berbekanja, Pengalaman Berbelanja dan Kepercayaan Konsumen Terhadap Minat Beli Konsumen di Situs Jual Beli Online Bukalapak.com. Semarang: Skripsi tidak diterbitkan.

Angelia, et al. (2020). Analysis of Community Institution Empowerment as a Village Government Partner in the Participative Development Process. Budapest International Research and Critics Institute-Journal (BIRCI-Journal), 1352-1359.

Artha, Herawati and Darmawan. (2014). Pengaruh Keahlian Audit, Konflik Peran dan Kompleksitas Tugas terhadap Audit Judgment (Studi Kasus pada Inspektorat Pemerintah Kabupaten Gianyar dan Kabupaten Bangli). Volume 2. Nomor 1.

Auditya, Lucy., Husaini and Lismawati. (2013). Analisis Pengaruh Akuntabilitas Dan Transparansi Pengelolaan Keuangan Daerah Terhadap Kinerja Pemerintah Daerah, JurnalFairness Vol 3, No. 1.

D Sunarsi. (2020). Kepemimpinan Bisnis Strategik. Kota Serang: Desanta Muliavisitama

Garini, Nadia. (2011). Pengaruh Transparansi dan Akuntabilitas Terhadap Kinerja Instansi Pemerintah Pada Dinas di Kota Bandung. Skripsi. Bandung. FE UNIKOM.

Garnita, Nita. (2008). Pengaruh Akuntabilitas Terhadap Kinerja Instansi Pemerintah. Studi Kasus Pada Balai Besar Bahan dan Barang Tekhnik. Skripsi. Bandung. FE Univ. Widyatama.

Halim, A. and Iqbal M., (2012). Pengelolaan Keuangan Daerah.UPP STIM YKPN: Yogyakarta

Halim, Abdul. (2002). Akuntansi Keuangan Daerah. Salemba Empat: Jakarta.

Hasibuan, H. Malayu SP. (2009). Manajemen Sumber Daya Manusia. Jakarta: PT. Bumi Aksara

Irfansyah. (2020). TheDutiesandFunctions Performance ofAceh Human Resources Improvement Institutions inScholarship Study ProgramImplementation inAceh Government. Britain International of Humanties and Social Sciences (BIoHS) Journal, 2685-3868.

Mahsun, Mohamad. (2006). Pengukuran Kinerja Sektor Publik. Yogyakarta : BPFE.

Mardiasmo, (2004). Otonomi dan Manajemen Keuangan Daerah. ANDI, Yogyakarta.

Mardiasmo. (2006). Perwujudan Transparansi dan Akuntabilitas Publik Melalui Akuntansi Sektor Publik: Suatu Saran Good Governance. Jurnal Akuntansi Pemerintahan. Vol. 2 No.1.

Nuraflah, C. A. (2020). The Communication Strategy of Government in Bulu Cina Village towards Prosperous Village. Britain International of Humanities and Social Sciences (BIoHS) Journal, 2685-3868.

Purnama, Fifit and Nadirsyah. (2016). Pengaruh Pengawasan Keuangan Daerah, Akuntabilitas, Dan Transparansi Pengelolaan Keuangan Daerah Terhadap Kinerja Pemerintah Daerah Pada Kabupaten Aceh Barat Daya. Jurnal Ilmiah Mahasiswa Ekonomi Akuntansi (JIMEKA)

Rahayu, Eti Dwi. (2008). Pengaruh Disiplin Kerja Dan Pengawasan Kerja Terhadap Efektivitas Kerja Pegawai Pada Badan Kepegawaian Daerah Kota Semarang. Universitas Negeri Malang. Fakultas Ilmu Sosial. Jurusan Ekonomi. 
Rahmanurrasjid, Amin, S.H. (2008). Akuntabilitas dan Trasparansi dalam pertanggungjawaban Pemerintah Daerah Untuk Mewujudkan Pemerintahan Yang Baik di Daerah Semarang : Universitas Diponegoro.

Sugiyono. (2012). Metode Penelitian Kuantitatif Kualitatif dan R\&D. Bandung:Alfabeta.

Sunarsi, D. (2017). Pengaruh Kepemimpinan Dan Budaya Organisasi terhadap Kinerja Karyawan Pada Cabang Pembantu Bank DKI Pondok Labu-Jakarta Selatan. JENIUS, $1(2), 21$.

Sunarsi, D. (2018). Pengembangan Sumber Daya Manusia Strategik \& Karakterisrik Sistem Pendukungnya : Sebuah Tinjauan. Jurnal Ilmiah MEA (Manajemen, Ekonomi, \& Akuntansi), 2(3), 178 - 194.

Ulum, Ihyaul. (2012). Audit Sektor Publik Suatu Pengantar. Bumi Aksara: Jakarta.

Wiguna, Made BS., Yuniartha G., and Darmawan N. (2015). Pengaruh Pengawasan Keuangan Daerah, Akuntabilitas Dan Transparansi Pengelolaan Keuangan Daerah Terhadap Kinerja Pemerintah Daerah Kabupaten Buleleng, e-Journal Vol. 3 No. 1.

Wijoyo, H. (2018). Analisis Pengakuan Pendapatan dan Beban Kontrak Konstruksi Pada PT. Wahana Tata Riau. Jurnal Ilmu Komputer dan Bisnis, 9(2), 2034-2043.

Wijoyo, H. (2020). Rancang Bangun Sistem Penjualan pada CV. Sukses Karya Abadi Berbasis Web. Jurnal Ilmu Komputer dan Bisnis, 11(1), 2306-2319. 